\title{
Improvement of retail pricing strategies in food distribution networks in terms of global competition (St. Petersburg's example)
}

\author{
Irina Tulyakova ${ }^{1, *}$, Elena Gregova ${ }^{2}$, Viktor Dengov ${ }^{1}$ and Azer Mustafaev ${ }^{1}$ \\ ${ }^{1}$ SPBU, Department of Economics, 199034 Saint Petersburg, Russia \\ ${ }^{2}$ University of Zilina, Faculty of Operation and Economics of Transport and Communications, \\ 01026, Zilina, Slovakia
}

\begin{abstract}
The global crisis that hit the world economy at the end of the first decade of the 21 st century has significantly affected Russia. Since 2014 and up until now, due to internal and external reasons, there has been an almost continuous decline in real disposable income of Russian households. Many Russian families are forced to economize down to the essentials. As is generally known, food costs are at the very bottom of Maslow's hierarchy of needs, and their reduction occurs in the last place. However, within this primary segment of consumption negative processes also occur; in determining the structure of costs the choice is cast over the quality of food and in favour of its affordability. Faced with the fall of its turnover, even large retail chains brands are forced to improve their pricing strategies in order to stabilize their falling revenues in the face of increasing competition. "How can they achieve this?" is the question the authors of two articles in this series attempt to answer. The first article examines problems associated with development of "customer loyalty programs", and proposes a model for improving the existing system of trade margins. The article also looks at the advantages and limitations of the proposed model.
\end{abstract}

Key words: Privatelabel, economic recession, households, food chains

\section{Introduction}

The food retail industry is one of the most important sectors of national reproduction, since it ascertains the national food safety. The food products, especially in the period of a prolonged recession, represent the crucial body of essential goods that the consumers will choose to spend their budgets on. The effective pricing strategies in the food retail market can lower the influence of the negative influence of the crisis upon the economy, as well as ensure a healthy consumption pattern of the population if coupled with the reasonable prices. In view of this, the study of the problems of the pricing strategies of the food retail industry is an urgent task, the solution of which may help to find the reference point for the

\footnotetext{
*Corresponding author: i.tulyakova@spbu.ru
} 
refinement of the sellers' long-term price strategies, when the market undergoes the period of a prolonged recession.

Within this work, the authors set themselves a goal to analyze the current situation in the St. Petersburg market of food retail and to offer some measures, substantiated by the economic calculations, for the perfection of the price strategies of the food sellers, currently suffering a loss of competitive position in their target market.

The authors of this study have already analyzed the situation in the St. Petersburg food retail market numerous times. In their first articles (2016), devoted to this topic, the goal of the research had been the evaluation of the concentration levels in the different segments of this market by means of a varied number of indices (CR, HHI, IL). As a result, the authors concluded that if in the 1990s the food retail market of St. Petersburg showed all signs of prominent monopolistic competition, its structure in the very first 15 years of the new age clearly bespoke a "blurred" oligopoly, with an average level of concentration for the industry as a whole. More than $80 \%$ of that market belonged to the 7 key companies, owning the 11 retail store chains [1,2]. The goal of our next study (2018) was to find the common traits and the peculiarities of the development of the retail business in the two major Russian cities - Moscow and St. Petersburg. Though the "two capitals" vastly differ both in size and population income, they are definitely comparable, since both of them had encountered the similar transformative changes in the course of their transition to the market economy.

The main conclusion, based on the results of that research, was that despite the serious slump, caused by the numerous external (such as sanctions etc.) and internal (such as the decrease in the real income of the population etc.) reasons, the food retail both in Russia as a whole and in its biggest megalopolises still retains its importance as one of the drivers for the possible stable development rates of the national economy. Simultaneously, both the country as a whole and its capitals was undergoing the continued process of concentration and centralization of the food retail market. We still consider that our previous conclusion about the type of St. Petersburg food retail market as the one of a "blurred" oligopoly is true. The analysis of the situation in Moscow and Russia as a whole, however, proved our presupposed hypothesis that even despite the leading positions of the major retail chains both in the country and its capital, this market leans more toward the monopolistic competition, than an oligopoly, however "blurred" [3].

\section{Theoretical and empirical bases of research}

We found the theoretic and methodological basis for our research in the works of both national and international authors. The theoretic base for the analysis of the pricing models were the publications of Cyert \& Marsh, Argote \& Greve [4, 5]. The analysis of the problem of price strategies used the works and studies of Samuelson \& Marks, Landsg [6, 7]. Some specific problems of pricing we cleared by using the publications of Hess \& Gerstner [8], the methods for the evaluation of the product competitive ability - learned from the work of Shpak et al. [9 The opportunities for the food export expansion, studied in the articles by Meyer \& Meyer and Meyer \& De Jongh [10-11], could also act as the factors, influencing the behavior of players on the internal market in the period of prolonged recession. In the research of the behavioral aspects of the irrational consumer choice we relied on the scientific heritage of Thaler, the globally renowned specialist in the field of the behavioral economy [12]. Within the context of our research, we found it useful to find out the certain similarities and differences in the behavior of the consumers in Russia, Slovakia and the Czech Republic [13,14].

As the empiric base for our research, we used the primary and secondary statistical and analytical information, related to the agenda of our studies. The data on the consumer 
preferences and reasons for their changes is the result of the authors' own questionnairebased survey of the customers of the major food retail chains. The statistical base for the research are the reports of the Russian Federal State Statistics Service and other analytical agencies, whose research interests correspond with the key topics of our research.

\section{The economic crisis and its impact on real incomes and consumer spending}

The recovery from the prolonged economic recession, in which Russia finds itself ever since 2014, is impossible without the growth of the real income of the population, which ensures about $45-50 \%$ of the aggregate demand for the products and services of the national GDP. However, as per the report of Federal State Statistics Service from January 2019, the real income of the Russian population has been steadily decreasing for 5 years. In 2014, they lowered by $0.7 \%$, in 2015 - by $3.2 \%$, in 2016 - by $5.8 \%$, in 2017 - by $1.2 \%$ and in 2018 - by $0.2 \%$ [15]. This tendency continues in 2019 as well. Within the first half of 2019 , the real income of the population has fallen by another $1.3 \%$. As a result, by the end of the first quarter of $2019,14.3 \%$ of the population (as compared to $13.9 \%$ in 2018) found themselves beyond the income poverty line. Due to the decrease of real incomes and the growing food prices, almost 21 million Russian people are living beyond the poverty threshold [16]. With the average wages within the country of 47,657 rubles (as of April 2019), the median wage is only 34,335 rubles, $27.9 \%$ lower, which is a well-known indicator of the significant inequality of income distribution [17]. The modal wage, as it turns out, is even lower - around 23.5 thousand rubles, that is, twice less than the average one. The people, whose monthly income does not exceed the official stated subsistence minimum, are officially "poor". In the first quarter of 2019, for the country as a whole this subsistence minimum was specified as 10,753 rubles, for St. Petersburg it is a little higher (11,055 rubles) [16]. Unlike the official statistics of the Federal Service, the surveys of the Public Opinion Foundation draw an even grimmer picture. According to the data of their survey from August 2019, the median wage (not income!) constitutes 21 thousand rubles (for the sample group of 1.5 thousand respondents). At the same time, almost $40 \%$ of the respondent's express dissatisfaction with their current salaries and would consider the wages of 25-45 thousand rubles as "more fair" [18]. In 2018, the Delovoy Peterburg (St. Petersburg Business) newspaper held an opinion poll for the economists and analysts of St. Petersburg, wherein it asked them, how much a St. Petersburg resident should earn, so as not to feel the negative influence of crisis. The opinions of analysts widely differed, and the necessary sum fell anywhere within the range from 33,750 to 200 thousand a month [19]. All the analysts, however, agreed on the fact that one can buy far less with the current money, than one could but a year before. Which means that the growth rate of prices far exceeds the growth rate of the wages. The sums named are not fictitious; they reflect the median expenditures of the median megalopolis resident. The minimal sum above includes the annual payments for the car amortization, insurance policies, taxes, utility charges and other compulsory payments. That is, presuming that you already own a small apartment and the most common no-frills car. It also includes the expenses for food, change of clothes, minimal gifts, medicine and the "rainy day" fund. Even the most modest calculation gives 33,750 rubles, which is actually far from real. Because the residents of St. Petersburg also pay for mortgages, education, emergency medical services, daily transportation etc. In view of the above-mentioned wages, one can conclude that level of income inequality within the city is considerably high. The subsistence minimum does not correspond to the real situation; the employers are not prepared to pay more to their employees and with the high product prices and not so high average wages, the standard of living in the city is far from glamorous. 
The decrease of the real income of the population naturally influenced its purchasing power and activity. If one looks on the histogram for the dynamics of the average receipt amount of a Russian person, built by the Romir research holding [20], one can notice that for the last three years (from August 2016 to August 2019) with due regard to the natural seasonal fluctuation the amount of the average receipt has hardly changed. It shows that, on the one hand, the consumers try to maintain their habitual level of consumption, yet, on the other hand, they largely achieve it by the quick (up to $25 \%$ a year) growth of the consumer indebtedness [21], which by the April 1, 2019 has reached 7.7 trillion rubles, with the total loan debt, including the mortgages, of 15.5 trillion rubles. The loan burden per the household in 2018 increased from 22 to $27 \%$, which in it caused the growth of both the number and total of the overdue debts [22].

It is worth mentioning that due to its historical and geographical situation, St. Petersburg attracts the attention of businesspersons not only from Russia, but also from the surrounding countries, such as Estonia and Finland. The transportation routes between St. Petersburg and the countries of the EC provide the ample opportunities for the development of trade, as well as the food industry, which is traditionally one of the dominant segments in the economy of the Northwestern district.

\section{The characteristics of the St. Petersburg retail market in the period of prolonged recession}

Since the day-to-day staples are always in high demand even at the time of economic crisis, the food retail is the most competitive niche. However, the consequences of the economic crisis influence the development of this industry, too. That being the case, the most appreciable damage befalls the weak market players, while the stronger ones get the additional chance to strengthen their market positions. Presently, there is a tendency for the substitution of the traditional forms of retail, such as markets, pavilions, stands and kiosks by the big chain outlets. At the same time, the competition between the major food retail chains of national or international significance is also growing. In these unstable times, when the purchasing power of the population is lowering, the most difficulties befall the regional and local retailers, which, if past experience is anything to go by, may lead to the decrease in the number of their outlets or even to their bankruptcy with the subsequent takeover by the larger players within the market. In this manner, the major companies increase their influence in the geographical market and simultaneously reduce the competition. Thus, the X5 Retail Group in 2015 absorbed the Rosinka retail chain, and in 2017 bought out 32 outlets of the O'Key chain and 99 outlets of the Polushka one.

The analysts point out that the chief development drivers for the food retail chains in the later years were such formats as a "discounter shop" or a "neighborhood store", with the flexible pricing policies and easy access. The retail chains that sell their products only in the hypermarket format, on the other hand, experienced serious problems and the decrease of profits. The clear example thereof are such powerful retailers as AUCHAN and METRO that feature only one format of shopping space organization.

The changes in the field of food retail are largely caused by the changes in the customer behavior. In the situation of the decrease of real incomes, the customers had to adapt to the new conditions. They became more discriminating: they buy less products, are more critical towards the salespersons, and pay more attention to the quality of products and their packaging. Their financial literacy has also increased; they have learned to choose the more cost-saving strategies. The long-term expectations of the consumers changed, they do not feel the stability any more. Such a change in the market behavior of the consumers brought about a stronger sensitivity towards the price changes. The recession itself may not be so deep, but the changed behavior of the consumers makes the recovery all the more difficult. 
The economic crisis is a systematic phenomenon, which affects all the variables that influence the aggregated consumer demand, be it the consumption, the taxes, the governmental expenditures or the income of the economic agents. In this circumstance, the retailers need to choose an optimal model of behavior to guide their actions and dynamic reactions to this crisis influenced environment.

According to the statistics, provided by the Federal Anti-Monopoly Service (FAS), the dynamics of the competitive positions of the food retail chains of St. Petersburg in this period of a prolonged economic recession has been quite diverse.

Table 1 shows the dynamics of the competitive positions of the major retail chains of St. Petersburg as of the beginning of 2018 (in relation to those of 2016).

Table 1. The changes in the competitive positions of the food retail chains of St. Petersburg, according to the FAS data

\begin{tabular}{|l|l|c|}
\hline $\begin{array}{l}\text { The company (group of } \\
\text { companies) }\end{array}$ & \multicolumn{1}{|c|}{ The trend in development } & $\begin{array}{c}\text { The change in market } \\
\text { share, \% }\end{array}$ \\
\hline $\begin{array}{l}\text { X5 Retail Group (Karusel', } \\
\text { Perekrestok, Pyaterochka) }\end{array}$ & Strengthening the competitive position & $+0,75$ \\
\hline Auchan & Strengthening the competitive position & $+2,57$ \\
\hline Lenta & Strengthening the competitive position & +0.75 \\
\hline O'Key & Weakening the competitive position & $-1,02$ \\
\hline Magnit & Strengthening the competitive position & $+0,7$ \\
\hline Dixy & Weakening the competitive position & $-0,81$ \\
\hline Polushka & Weakening the competitive position & $-0,87$ \\
\hline Prizma & Weakening the competitive position & $-0,15$ \\
\hline
\end{tabular}

Source: Delovoy Peterburg (15.06.2018) [online] Available at: https://www.dp.ru/a/2018/06/15/ X5_Retail_Group_ne_dostig (2019) (Own processing)

In our work, we analyzed all the chains, irrespective of whether their position on the market has weakened or strengthened in this period.

In the course of the practical part of our studies of the market's reaction towards the pricing strategies of the food retail chains in the times of recession, we carried out a marketing research in the form of written questionnaire-based survey of the customers of the said food retail chains with the subsequent analysis of the primary information. The main reason for the choice of this specific tool for our analysis were the advantages of the method itself. The primary information in the form of customers' feedback helps to explain the customer preferences toward a particular food retail chain and to establish to which extent these preferences depend on the pricing models of the companies in question. The analysis of the information clarifies the significance of the pricing policies of the food retail chains for the customers of diverse social categories in the situation of a prolonged economic recession and a decrease of the real income of the population. This tool helps us to establish the specific reference points for the refinement of the pricing models aimed on the preservation and sustenance of the effectual demand, since through it we can learn the real needs of the market.

We interviewed the focus group on December 10 to December 14, 2018 in the outlets of the above-mentioned food retail chains. The representative sample consisted of 74 respondents of diverse social categories. In analyzing the primary information, we used the tools for the analysis of statistic frequency distribution.

In the course of the analysis, we established the chief tendencies in the dynamics of the customer preferences, as well as the reason for the change of such preferences (relatively 
expensive prices, relatively un-profitable special offers and discount programs, narrowing product mix, bad quality etc.)) ${ }^{\dagger}$

\section{Measures for the refinement of the pricing strategies of the retail chains in the time of a prolonged recession}

In view of the changes in the customer preferences caused by the prolonged recession, all the retail chains have to refine their price strategies. Before the analysis of the possible models of the pricing behavior of the retailers in the times of recession, we should note that the product mix sold by the food retail sector is quite wide and includes the products with different price elasticity. This means that the pricing strategy for different groups of products should be diverse as well. In the other words, applying the same measures to all the items on sale alike will hardly be commercially effective.

Any possible pricing strategy or model of the behavior of an economic entity (irrespective of their line of business) should pursue the basic and inter-related objectives: maximization of profit, long-term maximization of the company value, preservation and increase of the market share, new market development.

We have analyzed the traditional models of business behavior in view of their capabilities and limitations in the times of recession. We are speaking about the pricing models focused on: a) cost-effectiveness; b) profit; c) demand; or d) competitive advantage. The pros and contras of all these models led us to the conclusion that the most suitable strategies for the times of a prolonged recession would be the ones that focus on the maintaining of steady demand and those that take into the account the activities of the competitors. The pricing strategies that emphasize the demand help the company to respond to the changes in the real incomes of the purchasers. The smart implementation of system of discounts and special offers can increase the sales of those products that otherwise (that is, with the "normal" prices) would have remained unsold and that the company would have to dispose of after the expiration date. With the strategies that take into the account the action of the competitors, on the other hand, the company can swiftly respond to the policies of the "pricing leaders", so that those cannot entice away their customers, for whom, in the times of crisis, the price becomes a more important incentive for the purchase than the brand.

Amid an economic recession, the pricing strategies that offer "loyalty programs" for the certain customer segments become the chief source of competitive advantage in the sales of primary commodities, including the food products [23]. One should take into the account that the majority of products sold by the food retailers are standard rather than distinctive. Thus, they cannot draw the competitive advantage from the concept of the product itself: the competitive advantages in the food market with the products of the same brands (due to the same suppliers) depend on the sales conditions, the chief of which is the price of the product. The further analysis suggests the following possible courses of development: a) the programs of discounts and special offers in regards of the specific groups of products; $b$ ) cumulative system of bonuses that could be used for the purchase of the products.

At that, one should understand that major food retail chains cannot operate without a certain permanent balance of the working capital in the sphere of circulation, and that means that they have to be profitable. That, in its turn, makes the development of strategies that would let them reach and maintain the certain profit margins even more urgent. In this way, the task of maintaining the commercial effectiveness of the business acts as a

\footnotetext{
$\dagger$ The analysis covered all the retail chains. Its detailed results are quite extensive and can be a subject for a separate article. If you are interested in them, you may contact the corresponding author.
} 
limitation for the development of measures for the optimization of the existing strategies, because the question that naturally arises is: how do you make the prices more customerfriendly without significant loss of profit?

This contradiction, in our opinion, could be largely solved by lowering the trading margins for those products, for which the values of such margins are the highest. Table 2 provides the analysis of the advantages of such an approach:

Table 2. The advantages of the lowering of the trading margins of the products with the highest margins for the preservation of the effective demand in the times of a recession

\begin{tabular}{|l|l|l|}
\hline \multicolumn{1}{|c|}{ Adjustable area } & \multicolumn{1}{c|}{ Strategic guidelines } & \multicolumn{1}{c|}{ The advantage of the strategy } \\
\hline Finance companies & Commercial Efficiency & $\begin{array}{l}\text { Allows you to keep positive profitability } \\
\text { ratios }\end{array}$ \\
\hline Enterprise Marketing & $\begin{array}{l}\text { The steady growth of } \\
\text { competitive position }\end{array}$ & $\begin{array}{l}\text { Allows you to maintain and increase } \\
\text { competitive positions by lowering prices }\end{array}$ \\
\hline
\end{tabular}

Source: Compiled by the authors

The main limitation for the implementation of this approach would be the lowering of the company's earning capacity under otherwise equal conditions, even if the business may still show profit. In analyzing this limitation, one should pay attention to the two important aspects:

1. In the times of recession, the economic agents encounter the risks of the worsening of the macroeconomic environment, the minimization of which is out of their control. In this case, the company development strategy should include the choice of finding either the maximin solution or the best possible one out of the available. If one compares the negative effects from the lowered earning capacity to those from the possible total loss thereof, the first solution seems more economically feasible. Moreover, nobody can predict, which kind of behavior would cause the company more potential losses: if it deliberately and consciously lowers the prices of the products with the highest trade margins; or if it leaves the prices as they are, to preserve the desired return on business ratio;

2. The lowering of prices will potentially strengthen the competitive positions of the company, that in the long run may lead to the growth of the company's market share and subsequently - to the increase in sales (the surplus inventory will be lower). As a result, the net income of the company will also grow.

Therefore, the chief vector of such a price management of the products with the highest trade margins may potentially provide a positive effect (alongside the negative). The only way one can measure it is by practically implementing this approach and subsequently analyzing the dynamics of the effective demand. Now, let us look on the groups of products, the trading margins of which we can optimize, and the potential effect of such optimization on the financial performance of the company (Table 3).

Table 3. The groups of products with the highest trading margins present in the food retail outlets of St. Petersburg, as of 2018-2019

\begin{tabular}{|l|c|}
\hline \multicolumn{1}{|c|}{ Commodity group } & Trade margin up to (\%) \\
\hline Fresh vegetables and fruits & 200 \\
\hline Dairy products & 50 \\
\hline Raw products: poultry, pork, beef, fish & 50 \\
\hline Alcohol and tobacco products & 300 \\
\hline
\end{tabular}

Source: DAIRYNEWS.RU: (25.03. 2019) [online] Available at: http://www.dairynews.ru/news/ segodna_torgovaja_nacenka_na_molochnuju_produkciju.html (Own processing)

Therefore, under otherwise equal conditions, the realization of goods in these groups can provide the return on costs (ROC) of 50 to $400 \%$, comparatively big figures for the retail trade (the average profit margins of the food retail in 2017 was $3.6 \%$ ). Thus, we may 
affirm that the lowering of the trading margins for these groups of products would not lead to the significant losses for the companies.

Another important thing is that most of these products, apart from the alcohol and tobacco, are perishable goods. In the other words, any food retail chain is interested in their quick realization, because they are the products that ensure the highest finished goods turnover of the company. Such products are in constant supply and generate a major part of the company's active (daily) profit.

By studying the catalogs of the food retail companies, whose positions in the market have weakened during the period of our analysis, we were able to calculate the average prices for the items in the above-mentioned categories (see below table 6). In view of the existing values of the trading margins as shown in Table 3 , the authors suggest their lowering by a certain number of percentage points for the stimulation of the effective demand. We also provide an illustration of the potential changes in the earning capacity of the company after the lowering of the products trading margins.

As you know, in the financial analysis, there are four groups of the profitability indices, used for the evaluation of the commercial effectiveness of the company (Table 4).

Table 4. Chief profitability indices, used for the analysis of the financial and operating performance of the company

\begin{tabular}{|l|l|l|}
\hline \multicolumn{1}{|c|}{ Indicator } & \multicolumn{1}{c|}{ Formula } & \multicolumn{1}{c|}{ Economic sense } \\
\hline $\begin{array}{l}\text { Return on assets } \\
\text { (ROA) }\end{array}$ & $R O A=\frac{\text { Net Income }}{\text { Average Total Assets }}$ & $\begin{array}{l}\text { Analytical value is a study of the cost-effectiveness } \\
\text { of the acquisition of certain assets }\end{array}$ \\
\hline $\begin{array}{l}\text { Return on equity } \\
\text { (ROE) }\end{array}$ & $R O E=\frac{\text { Net Income }}{\text { Shareholder Equity }}$ & $\begin{array}{l}\text { The target group of users is the owners of the } \\
\text { enterprise who want to track the effectiveness of } \\
\text { investments in it }\end{array}$ \\
\hline $\begin{array}{l}\text { Return on cost } \\
\text { (ROC) }\end{array}$ & $R O C=\frac{\text { Balance sheet profit }}{\text { Gross cost }}$ & $\begin{array}{l}\text { The target group of users are managers who optimize } \\
\text { the turnover and profitability of the production cycle }\end{array}$ \\
\hline $\begin{array}{l}\text { Return on sales } \\
\text { (ROS) }\end{array}$ & $R O S=\frac{\text { Balance sheet profit }}{\text { Revenue }}$ & $\begin{array}{l}\text { Informative if the company's profit is provided not } \\
\text { only by operating activities }\end{array}$ \\
\hline
\end{tabular}

Source: Compiled by the authors

In our opinion, for the food retail companies - with high turnover and short turnover cycles, the most meaningful index would be the return on cost one, since with it one can trace the day-by-day effectivity of the commodity circulation within the company: the retailer buys and sells new loads of goods and bears some expenses every day. In this respect, the return of profit on the expenses would be the most informative.

Under otherwise equal conditions, the unit costs of the company will be equivalent to the supplier's prices that they pay for the products. Table 5 presents the classification of the retailers' operating costs, depending on the distribution channels of particular food products.

Table 5. The operational costs of the retailers, according to the types of the distribution channels of the food products

\begin{tabular}{|l|l|l|}
\hline Channel Type & Description of the distribution channel & \multicolumn{1}{c|}{ Operating cost structure } \\
\hline $\begin{array}{l}\text { One-level } \\
\text { channel }\end{array}$ & $\begin{array}{l}\text { A retailer buys products from a } \\
\text { manufacturer }\end{array}$ & $\begin{array}{l}\text { Retailer transaction costs - manufacturer } \\
\text { purchase prices }\end{array}$ \\
\hline $\begin{array}{l}\text { Two-level } \\
\text { channel }\end{array}$ & $\begin{array}{l}\text { There is a wholesale intermediary } \\
\text { between the retail store and the } \\
\text { manufacturer }\end{array}$ & $\begin{array}{l}\text { Retail transaction costs - the purchase } \\
\text { prices of a wholesale intermediary, } \\
\text { including producer prices }\end{array}$ \\
\hline $\begin{array}{l}\text { Three-level } \\
\text { channel }\end{array}$ & $\begin{array}{l}\text { Between the retail store and the } \\
\text { manufacturer there are two } \\
\text { intermediaries - an agent dealer and a } \\
\text { wholesale intermediary }\end{array}$ & $\begin{array}{l}\text { Retail operating costs - purchase prices of } \\
\text { the agent, wholesale intermediary and } \\
\text { manufacturer, expressed in the wholesale } \\
\text { price }\end{array}$ \\
\hline
\end{tabular}

Source: Compiled by the authors 
As evident from the Table 5, depending on the distribution channel that the retail chain is a part of, its cost price may depend on the purchasing prices of different participants. However, the principle is the same: the cost of sales of the retailer depends primarily on the total volume of sales of the channel provider or the original manufacturer, who sold the products to the retailer.

In view of all the information above, we present you the final Table 6 that illustrates the selected approach to the lowering of prices for the products with the highest trading margin for the retail companies. Here, we would like to emphasize that all the products that we suggest for the lowering of the trading margin are only the consumer choice high-demand objects.

Table 6. The optimization of the pricing policy in regards of the products with the highest trading margin

\begin{tabular}{|c|c|c|c|c|c|c|}
\hline $\begin{array}{l}\text { Name of } \\
\text { product }\end{array}$ & $\begin{array}{c}\text { Average } \\
\text { price per } \\
\mathrm{kg}(1), \text { rub }\end{array}$ & $\begin{array}{c}\text { Max ROC } \\
\text { with current } \\
\text { margin, \% }\end{array}$ & $\begin{array}{c}\text { Suggested } \\
\text { price range, } \\
\text { rub }\end{array}$ & $\begin{array}{c}\text { New level of } \\
\text { ROC under } \\
\text { margin decline, } \%\end{array}$ & $\begin{array}{c}\text { Delta } \\
\text { prices, } \\
\%\end{array}$ & $\begin{array}{c}\text { Delta ROC, } \\
\%\end{array}$ \\
\hline \multicolumn{7}{|c|}{ vegetables and fruits (raw plant products) } \\
\hline Tomatoes & 190 & \multirow{5}{*}{200} & 139,3 & \multirow{5}{*}{120} & \multirow{5}{*}{26,6} & \multirow{5}{*}{-80} \\
\hline Cucumbers & 120 & & 88,0 & & & \\
\hline Apples & 104 & & 76,3 & & & \\
\hline Oranges & 80 & & 58,7 & & & \\
\hline Bananas & 60 & & 44,0 & & & \\
\hline \multicolumn{7}{|c|}{ Dairy products of animal origin } \\
\hline Milk & 72 & \multirow{5}{*}{50} & 67,2 & \multirow{5}{*}{40} & \multirow{5}{*}{6,6} & \multirow{5}{*}{-10} \\
\hline Sour cream & 151 & & 139 & & & \\
\hline Kefir & 83 & & 78 & & & \\
\hline Cottage cheese & 525 & & 490 & & & \\
\hline Cheese & 700 & & 649 & & & \\
\hline \multicolumn{7}{|c|}{ Other products of animal origin } \\
\hline Chicken fillet & 287 & \multirow{7}{*}{50} & 268 & \multirow{7}{*}{40} & \multirow{7}{*}{6,6} & \multirow{7}{*}{-10} \\
\hline Beef & 673 & & 618 & & & \\
\hline Pork & 419 & & 389 & & & \\
\hline Herring & 636 & & 593 & & & \\
\hline Trout & 1495 & & 1395 & & & \\
\hline Salmon & 1440 & & 1338 & & & \\
\hline Chicken egg & 58 & & 49 & & & \\
\hline \multicolumn{7}{|c|}{ Alcohol and tobacco products } \\
\hline Cigarettes & 170 & \multirow{4}{*}{300} & 127,5 & \multirow{4}{*}{200} & \multirow{4}{*}{26,6} & \multirow{4}{*}{-100} \\
\hline Vodka & 245 & & 184 & & & \\
\hline Cognac & 512 & & 384 & & & \\
\hline Wine & 734 & & 550 & & & \\
\hline
\end{tabular}

Source: Compiled by the authors based on: Ltd. "Prism" - catalog (Date of contact: April 2, 2019) Available at: http://tomall.ru/allmarket/prisma; Catalog of supermarkets "Polushka" (Date of contact: April 2, 2019) Available at: http://www.a-piter.ru/cena/polushka_skidki.html; Catalogs goods supermarket chain "Okay" (Date of contact: April 2, 2019) Available at: https://www.okmarket.ru/ customers/catalogs/

For a correct analysis of the suggestions presented in this study, we need to provide some explanations about the initial input variables. As it has been already mentioned above, 
we took the average prices for the products in question from the master catalogs of the retail chains, gradually losing their competitive edge. The basic assumption of this model of the pricing strategy development is that we used the maximum trading margins that a retailer in the market may add (in fact, the margins vary). For the products in the "Fruits and Vegetables" category, we suggest that, in the times of a recession, the margin should be lowered by $80 \%$. This figure in percent was set experimentally, based on the analysis of the maximally allowable lowering of the trading margin: since this is the product with a continuous flow (renewed every day during the active sales hours), the item cannot be marked down by $100 \%$, this product company brings the retailer significant amounts of profit. Yet, at the same time, the lowering of the trading margin should proceed, down to the level, which will make the price comparable to that of the companies that have strengthened their market positions (X5 Retail Group, Lenta, Auchan). That is why, in our opinion, the trade margin for this category should be marked down by $80 \%$. In the same manner we defined the maximum allowable limit for the lowering of the profitability of the other groups of products: dairy and meat, alcohol and tobacco.

The presented price-lowering model, used within the framework of the described pricing strategy, shows that even the very insignificant lowering of the trading margins can ensure a considerable lowering of the retail prices. Which makes the implementation of this strategy highly advisable in the times of a recession (especially in the periods of its aggravation). At the same time, the presented (and in fact, any) model has both its advantages and its limitations (see table 7).

Table 7. The advantages and limitations of the presented model of lowering the trading margins for the products with the highest margins

\begin{tabular}{|c|c|}
\hline \\
\hline Advantages & Limitations \\
\hline $\begin{array}{l}\text { Reflects a significant reduction i } \\
\text { consumers }(6.6 \text { and } 26.6 \% \text {, respe }\end{array}$ & $\begin{array}{l}\text { Possible ethical conflict regarding lower prices for } \\
\text { alcohol and tobacco }\end{array}$ \\
\hline \multirow{2}{*}{$\begin{array}{l}\text { Mostly prices do not reach round values, } \\
\text { which allows taking into account the } \\
\text { behavioral aspect of consumer choice }\end{array}$} & $\begin{array}{l}\text { Lack of reliable information on input variables } \\
\text { (maximum store margins) }\end{array}$ \\
\hline & $\begin{array}{l}\text { The impossibility of modeling the optimal value of } \\
\text { reducing the trade margin }\end{array}$ \\
\hline
\end{tabular}

Source: Compiled by the authors

In regards of the presented advantages, we need to add that the model really reflects an effective lowering of prices (by approx. 7 and 30\% respectively), which, in view of the decreasing real incomes of the population, can become a significant advantage for the pricing strategies of the target companies. Another important aspect to consider is the behavioral factor, which in this case means that the prices do not reach the so-called "round figures" and the customer instinctively associate the prices with first two figures on the price tag. This aspect acts as one of the empirical proofs for the assumptions of the behavioral economy theory, systematized by Thaler in 2017 [12], and disproves the classical and neoclassical approaches, according to which the consumer choice is supposed to be rational. In this way, the prices, calculated as the result of lowering of the presumably high margins, also stimulate the irrational aspects of the consumer choice.

At the same time, the implementation of this model has certain limitations. Primarily, we need to emphasize the ethical aspect, related to the concept of lowering the alcohol prices. Since the lowering of the prices for the alcoholic products will, without a doubt, stimulate the demand, such a measure may cause considerable social damage. In view of that, we could have dropped alcohol and tobacco from the groups of goods, that would be subjected to any kind of stimulating policy, to begin with. However, if to reach some particular necessary profit levels the retailer finds it advantageous to apply the stimulating measures towards these groups of products, from the economical point of view (let us temporarily set aside the ethical one), he certainly can. 
The second limitation pertains to the analysis itself. In the situation of the information asymmetry and, in particular, lack of precise and trustworthy information on the trading margins for specific goods, the precise calculation for each individual group of products becomes impossible. Thus, the values acquired within the framework of our model should be taken as hypothetic, provided only to show the general direction for the application of the strategy.

The third limitation is the impossibility of creating a model of an optimal trading margin, since the modeling of the optimal price is a priori impossible. This, in its turn, is explained by the following factors:

- the point differences in the incomes of the representatives of the target-segments: the product is standard and intended for the mass market, and the salespersons deal with the customers of different socioeconomic groups;

- the influence of the behavioral factors on the consumer choice (psychological motives, emotional state, biased attitude to a particular brand);

- the fact that it is impossible to precisely forecast the client stream and its structure according to different criteria.

The model does not let us calculate an optimal trading margin, since one can never take into the account all the multitude of the factors, both qualitative and quantitative. Thus, one calculates the trading margins, according to that information, which is available, and then has to necessarily test them experimentally.

Nevertheless, the idea of managing the clients' loyalty by the changing of trading margins for the groups of products with the highest margins may be of a strategic interest for the development of the food retail chains in the times of a prolonged recession.

\section{Conclusions}

The process of the analysis leads us to the following conclusions:

1. The food retail is an important part of the reproduction process and ensures the food, and in a wider view, also the economic safety of any country [24]. The food products, especially in the period of a prolonged recession, represent the crucial body of essential goods that the consumers will choose to spend their budgets on. The food products predominantly belong to the group of primary commodities with low price elasticity. Yet, the prolonged economic recession, in which Russia finds itself ever since 2014, didn't spare this important sector of the economy from its negative influence. The real incomes of the population have been falling for five years. The number of households, living beyond the poverty threshold is steadily growing. To keep up the habitual consumption level, many households have to resort to the bank loans. The credit indebtedness, especially in the poorer part of the population is growing on a rapid rate, as well as the number and amounts of the overdue debts. The consumption is in stagnation. In a feedback effect, this whole situation negatively affects the GDP growth and the economic recovery. The competition between the chain retailers for the dwindling income of the population is stiffening and leads to the re-partition of the market. All the players, and especially those, whose position has weakened in the period of a recession, face an urgent task of the development of an effective pricing strategy. Its successful solution can not only lower the negative influence of the crisis upon the food market, but also, in connection with the budget-friendly prices, stimulate the normal consumption by the population.

2. The food retail market of St. Petersburg, thanks to its history and specific geographic location, has a number of advantages over the other regions. Yet, it also suffers from the effects of the current crisis. The prolonged recession and the decrease of the real incomes significantly influences the customers behavior. Their financial literacy is higher, the number of impulsive purchases is less, and the special offers and discount programs are becoming more and more popular. The new decisive factor for the customer behavior is the 
price, not the preference for a specific brand. The retail chains that failed to notice these changes and react to them quickly have partially lost their market positions. The market survey, based on the representative sample of customers, helped us to clarify the reasons of the change in the customers' attitude towards this or that particular retail chain.

3. The smart discount policy and the price regulation policy are the distinctive factors of stimulating of the customer demand in the times of a recession: cumulative loyalty programs, discounts, special offers and other promotional events. In the situation of a prolonged recession, in planning of the pricing policy and promotional events, one should primarily rely on the principle of alternative costs, that is, compare the potential losses on one event and the other, because the losses are unavoidable. We also established, that the retailers should pay attention to the "price/quality" ratio, when they decide on a particular discount program, because the customer is not always ready to pay even the lowest of prices, if the quality so low, it is not even on par with that price. In planning the promotional pricing measures the retailers should also take into the account the behavioral factors of the customer choice: the increased sensitivity to losses rather than gains and the special disposition towards the salesperson's loyalty [25].

4. The optimization of the trading margins for the products with quick turnover and high margins can become one of the effective mechanisms for the promotion of the customer loyalty and preservation and strengthening of the company's competitive position. The inflow of new clients can compensate the initial insignificant loss of profit. The model of the changing of the trading margins for specific categories of goods, that we suggested, despite all its limitations can be used by the major retail chains for the refinement of their pricing policies.

\section{References}

1. A. Maksimov, V. Dengov, I. Tulyakova, Globalization in the field of food retail St. Petersburg: concentration and competition. Globalization and its Socio-Economic Consequences, 16th International Scientific Conference Proceedings. Rajecke Teplice, Slovakia (2016)

2. V. Dengov, E. Gregova, A. Maksimov, Globalization in the field of food retail St. Petersburg: analysis of the price policy. Globalization and its Socio-Economic Consequences, 16th International Scientific Conference Proceedings. Rajecke Teplice, Slovakia (2016)

3. E. Gregova, V. Dengov, I. Tulyakova, Global Trends in Russian Retail: a Comparison of the Market of St. Petersburg and Moscow. Globalization and its Socio-Economic Consequences, 18th International Scientific Conference Proceedings. Rajecke Teplice, Slovakia (2018)

4. R. Cyert, J. Marsh, A Behavioral Theory of the Firm. (Wiley-Blackweel, London-NY, 1992)

5. L. Argote, H. Greve, A Behavioral Theory of the Firm - 40 Years and Counting: Introduction and Impact. Organization Science 18(3), 337-349 (2007)

6. W. Samuelson, S. Marks, Managerial Economics. (Wiley, London-NY, 2014)

7. S. Landsg, Price Theory and Applications. (Cengage Learning, Boston, MA, 2013)

8. J. Hess, E. Gerstner, Loss Leader Pricing and Rain Check Policy. Marketing Science 6, $1-18(2001)$

9. N. Shpak, N. Seliuchenko, V. Kharchuk, N. Kosar, Wł. Sroka, Evaluation of Product Competitiveness: A Case Study Analysis. Organizacija 52, 107-125 (2019) 
10. N. Meyer, D. Meyer, An econometric analysis of entrepreneurial activity, economic growth and employment: The case of the BRICS countries. Journal of Economic \& Management Perspectives 11, 429-441 (2017)

11. N. Meyer, J. De Jongh, The Importance of Entrepreneurship as a Contributing Factor to Economic Growth and Development: The Case of Selected European Countries. Journal of Economics and Behavioral Studies 10, 287-299 (2018)

12. R. H. Thaler, Misbehaving: The Making of Behavioral Economics. (W. W. Norton \& Company, NY, 2015)

13. M. Psárska, Theoretical and practical view of development and differences in the application of productive consumption components in Czech and Slovak households under current economic conditions. SHS Web of Conferences (IES2018) 61, 01020 (2019)

14. M. Psárska, Determinants of real decision making on productive components of consumption under the current economic conditions of the Slovak Republic. SHS Web of Conferences (IES2018) 61, 01019 (2019)

15. The Russian Federal State Statistics Service: Information on the Socio-Economic Situation of Russia: 2018. [online], Available at: http://www.gks.ru/free_doc/doc_2018/ info/oper-12-2018.pdf (2019)

16. RosBiznesConsulting : Pochemu uroven bednosti v strane ne snizhaetsia (accessed on 28 August 2019) [online] Available at: https://www.rbc.ru/economics/29/07/2019/ 5d3eed879a7947952fc35485 (2019)

17. RosBiznesConsulting: Polovina rossiian zarabatyvaiut menee 35 tys $v$ mesiats (accessed on 28 August 2019) [online] Available at: https://www.rbc.ru/economics/18/07/ 2019/5d3039e39a79476266abb143 (2019)

18. KOMMERSANT.RU: Zarplata prosit udvoeniia (12.08.2019) [online] Available at: https://www.kommersant.ru/doc/4059274 (2019)

19. Delovoy Peterburg (27.04.2016) [online] Available at: https://www.dp.ru/a/2016/04/26/ Chto takoe horoshaja_zarplat (2016)

20. The research holding Romir : Sredniy chek prodoljaet medlenno hudet (14.06.2019) [online] Available at: https://romir.ru/studies/sredniy-chek-prodoljaet-medlenno-hudet (2019)

21. Vedomosti (24.06.2019) [online] Available at: https://www.vedomosti.ru/ economics/ blogs/2019/06/24/804789-potrebitelskoe-kreditovanie (2019)

22. A. Galanina, I. Grigoreva, Dolgovoi iashchik obemnvziatykh rossiianami zaimov dostig1486 trln. Information portal IZ.RU (27.02.2019) [online] Available at: https://iz.ru/850394/angelina-galanina-inna-grigoreva/dolgovoi-iashchik-obemvziatykh-rossiianami-zaimov-dostig-1486-trln (2019)

23. T. Jambal1, J. Stuchly, Customer evaluation of loyalty programs in selected companies of the South Bohemian region. SHS Web of Conferences (IES2018) 61, 01007 (2019)

24. V. Urazgaliev, E. Korostyshevskaya, G. Menshikova, Forming of collective and economic security within the framework of un conception of the peacebuilding Globalization and its Socio-Economic Consequences, 16th International Scientific Conference Proceedings. Rajecke Teplice, Slovakia (2016)

25. J. Hollowell, Z. Rowland, T. Kliestik, J. Kliestikova, V. Dengov, Customer loyalty in the sharing economy platforms: How digital personal reputation and feedback systems facilitate interaction and trust between strangers. Journal of Self-Governance and Management Economics 7, 13-18 (2019) 